\title{
Varied phenologies of Batrachospermum gelatinosum gametophytes (Batrachospermales, Rhodophyta) in two low-order streams
}

\author{
Samuel A. DRERUP \& Morgan L. VIS
}

\author{
Department of Environmental and Plant Biology, Ohio University, Athens, OH 45701, U.S.A.; *Corresponding \\ authore-mail: sd136405@ohio.edu
}

\begin{abstract}
The freshwater red algal species, Batrachospermum gelatinosum, is common in temperate/boreal regions North America and Europe. In southeast Ohio, gametophytes of this taxon were observed to have two different phenologies; in one stream the gametophytes were present only during the spring months and in another stream they were present year-round. Therefore, the purpose of this study was to determine environmental parameters associated with occurrence, peak vegetative growth and reproduction for $B$. gelatinosum gametophytes in these two streams. Field sampling was conducted for 18 months with both streams being sampled every three to four weeks, when possible. Physical and chemical parameters of stream depth, current velocity, $\mathrm{pH}$, conductivity and nutrients were measured each sampling date. Algal thalli were measured for changes in both vegetative and reproductive characters. In both streams, algal reproductive structures were positively correlated with stream depth $(7-52 \mathrm{~cm})$, but there was no correlation of vegetative characteristics with environmental variables measured. Algal cover $(0-50 \%)$ in each stream was positively correlated with stream depth $(7-52 \mathrm{~cm})$, current velocity (BDL-1.08 m.s $\mathrm{s}^{-1}$ ) and day length $(10.3-15.1 \mathrm{hrs})$. The site with the least canopy cover and greatest water depth had the highest algal cover and gametophytes present year-round; whereas the site with lower water depth had lower algal cover and gametophyte present only during spring and early summer. This result suggests that stream size and amount of riparian vegetation may play a role in determining phenologies observed. Contrasting phenologies have been reported for $B$. gelatinosum from sites that are geographically distant, but this study has found that local physical factors may produce differing phenologies in streams only a few kilometers apart.
\end{abstract}

Key words: Batrachospermum gelatinosum, freshwater, Ohio, red algae, river, seasonality

\section{INTRODUCTION}

The freshwater red algal genus Batrachospermum is distributed worldwide occurring primarily in streams and rivers, but taxa are also found occasionally in lentic waters (SHEATH \& НАMBRoOK 1990). Batrachospermum gelatinosum (L.) DC. is the nominate species of the genus and has been noted from locations in both the Northern and Southern Hemispheres (Entwisle \& KRAFT 1984; VIs et al. 1996). However, it has been shown that specimens attributed to this species from the Southern Hemisphere are a morphologically similar, but distantly related species, B. pseudogelatinosum (VIS \& Entwisle 2000). In the Northern Hemisphere, this taxon has been collected in North America, Europe and Asia (Kumano 2002). To date, there are sequence data showing the close relationship between specimens from North America and Europe confirming their recognition as the same species (House et al. 2010). Since similar data have not yet been generated for Asian records, it is unclear if specimens with the same morphology represent this species.
In North America, B. gelatinosum has a wide distribution occurring from the tundra in the North to the southeastern coastal plain in the South and appears to be present in streams of varying physical and chemical parameters (VIs et al. 1996). The ranges in morphological characters showed some trends when pooled by biome with smaller whorl diameter and larger carpogonium size in the tundra as compared with the coastal plain. In that same paper, the researchers showed that specimens from Newfoundland and Rhode Island had almost as much variation in various morphological characters measured throughout the year in three streams as was recorded across the geographic range (VIs et al. 1996). A phylogeographic study of this taxon in eastern North America found little genetic variation throughout most of its geographic range, but again specimens were plastic in their morphology (House et al. 2010).

Within the Batrachospermales, phenological research has been the emphasis of a few studies and other studies have included seasonality data for gametophytes (SheAth \& HAMBrooK 1990; table 16-6 
reference therein). Twelve species of Batrachospermum were listed by SHEATH \& HAMBROOK (1990), but many have been synonymized reducing the number to seven; two Lemanea species and Sirodotia suecica Skuja were also studied. More recent phenological studies have primarily focused on Lemanea, Paralemanea, Sirodotia species and a single Batrachospermum species, B. turfosum (VIs et al. 1991; MulLER et al. 1997; NeCCHI \& BRANCO 1999; FiLKIN \& Vis 2004; CARmona et al. 2009). The above studies point to varying seasonality of gametophyte production and in some cases gametophytes that are present year-round.

The phenology of $B$. gelatinosum has been documented in a few studies. Two earlier studies of this species (as B. moniliforme) have provided conflicting seasonality with April-October in Sweden and October-August in Rhode Island (KYLIN 1912; SHEATH \& BurKholder 1985). A more recent study, noted that B. gelatinosum from a stream in Spain was present only in the spring and summer when sampled seasonally (CARMONA et al. 2011). In a systematic study of specimens from North America, gametophytes were recorded year-round in two Newfoundland streams and from October-June in a Rhode Island stream (VIS et al. 1996). With these three studies, the linkage between phenological events in $B$. gelatinosum and stream parameters was not the focus as Sheath \& Burkholder (1985) were examining the whole macroalgal community, VIs et al. (1996) were documenting morphological variation and KYLIN (1912) was describing Batrachospermum species that occur in Sweden. Therefore, more research centered on the phenology of this taxon is warranted.

In southeastern Ohio, $B$. gelatinosum gametophytes have been collected in two streams that are relatively close $(\sim 14 \mathrm{~km})$ to each other, but in two different drainage basins. Gametophytes from both locations have been shown previously to be genetically identical using the cox 1 barcode region (House et al. 2010). Nevertheless, the gametophytes from one stream have been observed to be present more often than the other. Therefore, the present study was initiated to examine in detail the seasonality of $B$. gelatinosum gametophytes and the physical and chemical parameters in two streams in order to elucidate potential important factors related to its phenology.

\section{Materials and Methods}

Gametophyte thalli of $B$. gelatinosum were studied in two streams, Big Bailey Run $\left(39^{\circ} 24^{\prime} 55.3^{\prime \prime} \mathrm{N}, 82^{\circ} 7^{\prime} 8.62^{\prime \prime} \mathrm{W}\right.$; elevation $200 \mathrm{~m}$; drainage area $12.4 \mathrm{~km}^{2}$ ), which is a tributary in the Sunday Creek drainage basin and the main stem of Monday Creek $\left(39^{\circ} 30^{\prime} 2.02^{\prime} \mathrm{N}, 82^{\circ} 14^{\prime} 46.75^{\prime \prime} \mathrm{W}\right.$; elevation $210 \mathrm{~m}$; drainage area $195.3 \mathrm{~km}^{2}$ ) in Hocking County, Ohio, USA. Annual temperature and precipitation for Hocking County are approximately $10{ }^{\circ} \mathrm{C}$ and $100 \mathrm{~cm}$ respectively (ohiodnr.com/pubs). Both streams observed in this study occur in the Western Allegany Plateau (Level III, Ecoregion 70, USEPA). The Western Allegany Plateau consists primarily of mixed mesophytic forests with approximately $72 \%$ of the ecoregion being forested (landcovertrends.usgs.gov).

Field sampling was conducted for an 18-month period from June 2007 through November 2008. The streams could not be sampled December 2007 to March 2008 due to high water. Streams were sampled in three-week intervals May through September both years (when gametophytes were present in both streams) and monthly during the rest of the year, when possible.

Field parameters were enumerated with the aid of a 5 $\mathrm{m} \times 2 \mathrm{~m}$ area grid divided into $160625 \mathrm{~cm}^{2}$-quadrats. Water depth, current velocity, and percent $B$. gelatinosum were recorded in each quadrat. Five thalli, one each from five quadrats, were selected using a random number generator to choose the quadrat and preserved in $2.5 \%$ calcium carbonate-buffered glutaraldehyde. Water temperature, conductivity, and $\mathrm{pH}$ using handheld probes (Waterproof ECTestr ${ }^{\circledR}$ and pHTestr $30 \AA$, Oakton, Vernon Hills, Illinois, USA) were recorded on each sampling date and both filtered and unfiltered water samples were collected for chemical analyses. Canopy cover was determined using hemispherical photography. Images were taken once during leaf-on and again during leaf-off with percent cover determined using ImageJ software (Research Services Branch, National Institute of Mental Health, Bethesda, Maryland, USA).

Stream water was filtered using a $0.7 \mu \mathrm{m}$ pore sized glass fiber filters and was used to determine inorganic phosphorus (method 8048) and nitrogen (method 8192) using the Hach DR/890 colorimeter (Hach Company, Loveland, Colorado, USA). Turbidity was determined from the unfiltered water sample using a Hach 2100P turbidity meter (Hach Company, Loveland, Colorado, USA). Both the filtered and unfiltered samples were processed within 24 hours.

In the laboratory, thalli were examined for morphological characteristics. For each thallus, the overall length was measured. The characteristics of maximum whorl width, whorl number, and number of carposporophytes per centimeter were also recorded from intact thalli. Eight whorls located in the middle portion of the main axis were selected and homogenized using a razor blade. The homogenized sample was examined and the total number of spermatangia (mature and immature), and fertilized carpogonia were enumerated.

Statistical analyses were conducted using the " $R$ : A Language and Environment for Statistical Computing" software (R Development Core Team, Vienna, Austria). Assumptions of homogeneity and normality were tested using the Bartlett's Test of Homogeneity of Variances ( $p$ $>0.05)$ and the Shapiro-Wilk Normality Test $(p>0.05)$, respectively. Variables (percent algal cover, water depth, and $\mathrm{pH}$ ) not meeting the assumptions of heterogeneity or normality were $\log$ transformed. Percent cover values were converted to a modified Braun-Blanquet cover scale to account for variations in the estimates (SHEATH \& Burkholder 1985). Scaled values were then used for statistical analysis. Stream morphology and chemical conditions were compared using Student's t-test (significance level of 0.05 ). To identify how environmental conditions affected algal morphology, multiple linear regressions were used. The appropriate linear model was determined using stepwise model selection using Akaike's Information Criteria. 


\section{RESUlts}

The stream sites at Big Bailey Run and Monday Creek exhibited similar physical and chemical conditions with few significant differences (Table 1). Big Bailey Run had significantly greater phosphate concentration than Monday Creek $(\mathrm{p}<0.05)$, while Monday Creek had significantly greater mean water depth $(p<0.05)$ than Big Bailey Run. Big Bailey Run had higher percent canopy cover compared to Monday Creek during leaf on ( $73.7 \%$ and $50.4 \%$, respectively) and leaf off $(40.6 \%$ and $25.6 \%$, respectively). In both streams, water depth and current velocity were positively correlated $(\mathrm{p}<0.001)$.

There were differences in the morphological characteristics of the gametophytes between the two stream sites. Thalli were significantly $(\mathrm{p}<0.001)$ longer in Monday Creek than Big Bailey Run (Table $2)$. The number of whorls per centimeter $(p<0.05)$ was significantly greater in Monday Creek. There were no other significant differences in the morphological characters measured between these two sites.

Variation among sampling dates was observed in vegetative and reproductive morphological characteristics measured for gametophytes in both streams (Table 2). Gametophytes from Big Bailey Run showed much greater variation than those from Monday Creek. Seasonal pattern in variation was only observed in mean number of carposporophytes per whorl and was lowest in Big Bailey Run in the months of July and August of both years as well as in April $2008(p<0.05)$. In Monday Creek, mean number of carposporophytes per whorl was lowest in October of 2007 and August of $2008(\mathrm{p}<0.05)$.

Phenological differences were observed in the two populations of $B$. gelatinosum. Gametophytes in Big Bailey Run were seasonal, being present only from April to August in both study years (Table 2). However, the Monday Creek gametophytes were present on all sampling dates in both years. In both streams, the highest algal cover was observed in May and June, suggesting peak gametophyte growth occurs at this time in this region.

An inverse relationship between algal cover and canopy cover was observed, with times of greatest percent algal cover coinciding with times of minimal canopy cover. Results of the multiple linear regression identified positive relationships between water depth and percent algal cover $\left(p<0.05, R^{2}=0.50\right.$, Fig. 1a). As well, current velocity $\left(p<0.05, R^{2}=0.21\right.$, Fig. $\left.1 b\right)$ and day length $\left(p<0.05, R^{2}=0.15\right.$, Fig. $\left.1 c\right)$ were positively correlated with percent algal cover. Interestingly, nitrogen and phosphorus showed no significant relationship with percent algal cover. Although $\mathrm{pH}$ was also identified as a strong predictor of percent algal cover $\left(p<0.05, R^{2}=0.46\right)$, there was no significant difference observed between streams ( $p>0.05)$.

Algal reproductive structures were positively
Table 1. Physical and chemical parameters for the two stream segments containing Batrachospermum gelatinosum gametophytes throughout the study period. Mean with range below [BDL $=$ below detectable limit $\left.\left(0.1 \mathrm{~m} \cdot \mathrm{s}^{-1}\right)\right]$

\begin{tabular}{lll}
\hline & $\begin{array}{l}\text { Big Bailey } \\
\text { Run }\end{array}$ & $\begin{array}{l}\text { Monday } \\
\text { Creek }\end{array}$ \\
\hline Water Depth $(\mathrm{cm})$ & 13 & 22 \\
& $7-28$ & $11-52$ \\
Current Velocity $\left({\left.\mathrm{m} . \mathrm{s}^{-1}\right)}\right.$ & 0.26 & 0.12 \\
& BDL-0.95 & BDL-1.08 \\
Water Temperature $\left({ }^{\circ} \mathrm{C}\right)$ & 18.6 & 18.7 \\
& $7-25$ & $6-24$ \\
Turbidity $(\mathrm{NTU})$ & 6.80 & 7.07 \\
& $2.4-17.1$ & $1.18-20.9$ \\
Tree Canopy Cover $(\%)$ & 73.7 & 50.4 \\
(Leaf On) & & \\
Tree Canopy Cover $(\%)$ & 40.6 & 25.6 \\
(Leaf Off) & & \\
pH & 7.7 & 7.3 \\
& $6.9-8.3$ & $6.2-8.5$ \\
Conductivity $\left(\mu \mathrm{S} . \mathrm{cm}^{-1}\right)$ & 583 & 740 \\
& $230-1050$ & $60-940$ \\
Nitrate/Nitrite $\left(\mathrm{mg} . \mathrm{l}^{-1}\right)$ & 0.10 & 0.11 \\
& $0.01-0.30$ & $0.02-0.2$ \\
Inorganic Phosphate $\left(\mathrm{mg} .1^{-1}\right)$ & 0.19 & 0.12 \\
& $0.00-0.47$ & $0.02-0.35$ \\
\hline
\end{tabular}

related to water depth. The mean number of spermatangia per whorl significantly increased $\left(\mathrm{p}<0.01, \mathrm{R}^{2}=0.40\right)$ with mean water depth (Fig. 2a) and the mean number of carposporophytes per whorl $\left(p<0.01, R^{2}=0.36\right.$, Fig. 2b). Inversely, the mean number of carpogonia per whorl $\left(p<0.05, R^{2}=0.14\right.$, Fig. $2 c)$ showed a negative relationship with water depth in both streams. The vegetative characteristics measured for the gametophytes (thallus length, whorl diameter, and mean number of whorls per centimeter) showed no significant relationship with any of the measured environmental variables (Tables 1,2).

\section{Discussion}

Even though the overall seasonality was different, with gametophytes being present only part of the year in Big Bailey and year-round in Monday Creek, peak growth for both populations occurred in spring (May-June). Both the size of the thalli and the percent cover showed this trend. This finding is similar to observations of Batrachospermum sp. in a Kentucky stream that had peak growth in May (MinckLey \& 


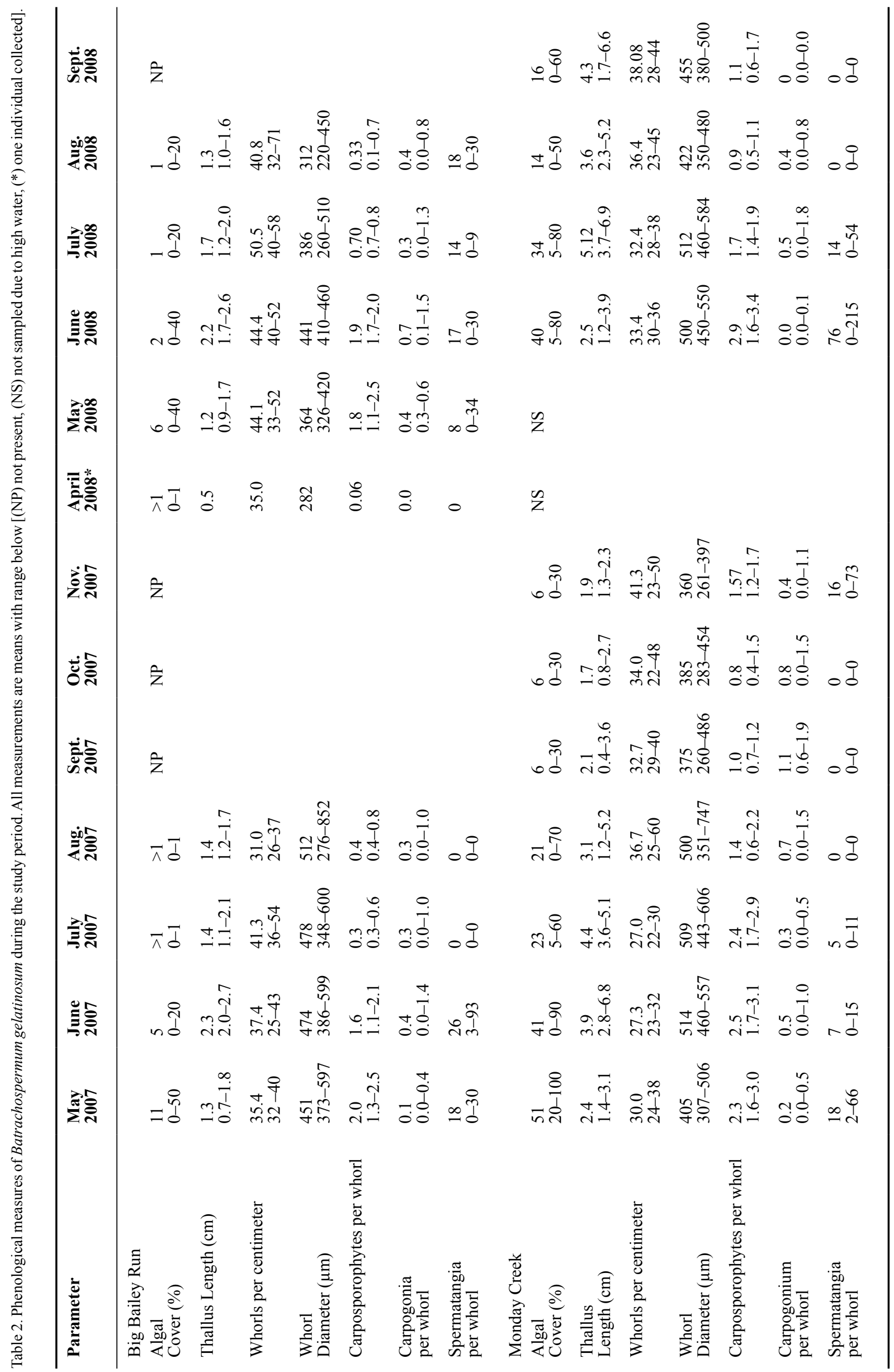


A

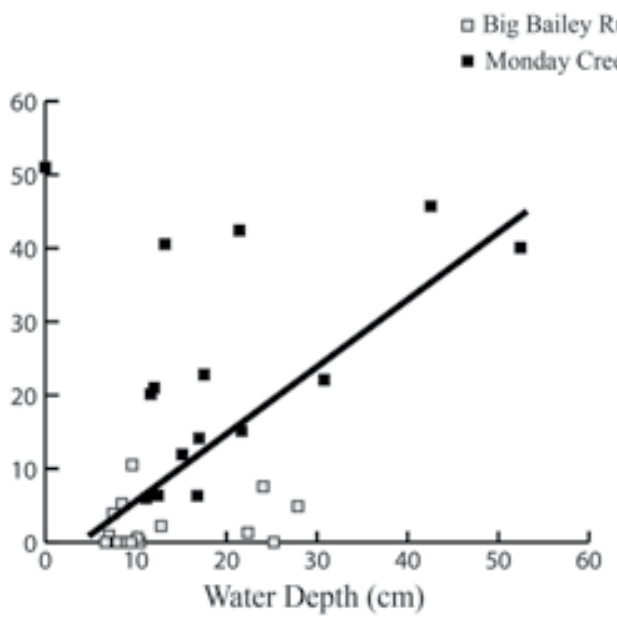

B

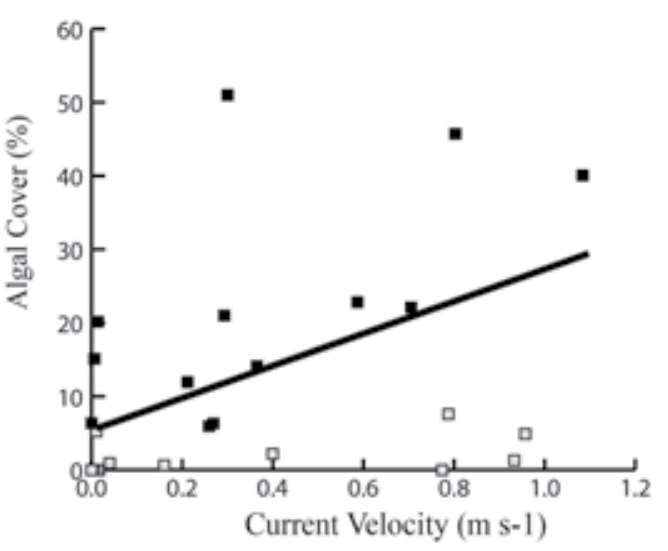

$\mathrm{C}$

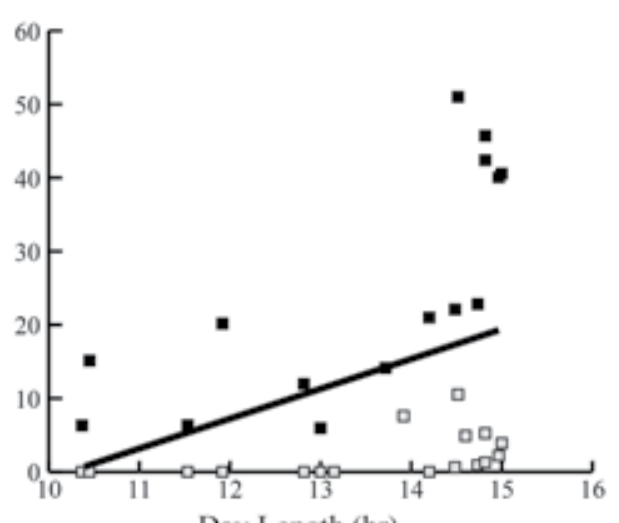

Day Length (hr)

Fig. 1. Percent algal cover of Batrachospermum gelatinosum in Big Bailey Run (grey squares) and Monday Creek (black squares) was positively correlated to (A) water depth $\left(\mathrm{p}<0.01, \mathrm{R}^{2}=0.50\right)$, (B) current velocity $\left(\mathrm{p}<0.05, \mathrm{R}^{2}=0.21\right)$, and $(\mathrm{C})$ day length $(\mathrm{p}<0.05$, $\mathrm{R}^{2}=0.15$ ).

Tindall 1963). In addition, the freshwater red alga, Paralemanea annulata (Kützing) M.L.Vis et Sheath, showed the greatest percent cover from April to June in a nearby southeastern Ohio stream (FILKIN \& VIS 2004). However, our results for $B$. gelatinosum are contrary to those of BuRKHOLDER \& SHEATH (1985) who observed relatively consistent percent cover of $B$. gelatinosum (as B. moniliforme) from October to April in two Rhode Island streams. Although these results differ, they
A a Big Bailey Run

- Monday Creek



B

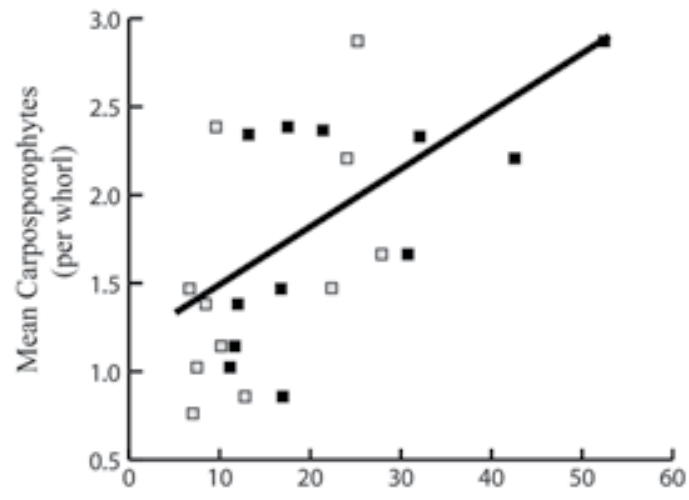

c



Fig. 2. Reproductive structures of Batrachospermum gelatinosum in Big Bailey Run (grey squares) and Monday Creek (black squares) were significantly related to water depth. (A) Mean spermatangia per whorl $\left(\mathrm{p}<0.01, \mathrm{R}^{2}=0.40\right)$, (B) mean carposporophytes per whorl $\left(\mathrm{p}<0.01, \mathrm{R}^{2}=0.36\right)$, (C) Mean carpogonia per whorl $(\mathrm{p}<0.05$, $\left.\mathrm{R}^{2}=0.14\right)$.

may point to the importance of canopy cover. In the Rhode Island streams, B. gelatinosum was only present when the leaves were off the trees. In our streams, an increase in percent cover was observed right before leaf out and in Big Bailey with a more closed canopy, the thalli quickly disappeared after leaf emergence. Similar observations of thallus disintegrated with the development of canopy leaves have been recorded for other species of Batrachospermum by other researchers 
(Minckley \& Tindall 1963; Hambrook \& Sheath 1991).

Both day length and current velocity were positively correlated to algal cover in this study. Only a single study of Lemanea fucina Bory in Rhode Island has shown day length and cover to be correlated (VIS et al. 1991). In contrast, numerous studies of various freshwater red algae have found a positive relationship between current velocity and algal cover or algal occurrence (MINCKLEY \& TindAll 1963; Rider \& Wagner 1972; Burkholder \& SheATH 1985; FILKIN \& VIS 2004). This result was not surprising, as many researchers have noted that freshwater red algae tend to be in lotic rather than lentic waters with peak occurrence in moderate flow (SHEATH \& HAMBROOK 1990 and the references therein).

In our study, water depth was positively correlated to both algal cover and abundance of reproductive structures. However, in previous studies that have shown a correlation, the highest percent algal cover has been during times of lower stream depth (Sheath \& Burkholder 1985; NeCChi \& Branco 1999; FilKIN \& VIS 2004; CARMONA et al. 2009). This seemingly contrary result is difficult to interpret as the negative relationship between depth and algal cover is often qualitative or as a means to compare percent cover changes within a single stream over the course of a study, rather than a comparison of absolute numbers between streams.

Physical stream factors were more important to the seasonality and phenology than chemical factors in this study. Parameters such as water depth and current velocity were more often correlated to gametophyte characteristics than $\mathrm{pH}$, conductivity and nutrients. Researchers studying springs that vary little throughout the year in chemistry have found similar results showing physical parameter to be significant (Minckley \& Tindall 1963; Rider \& Wagner 1972). Like the present study, other researchers have not observed a relationship between nutrients and algal percent cover (SHEATH \& BuRKhOldER 1985; ThIRB \& Benson-Evans 1985).

Gametophyte seasonality of $B$. gelatinosum appears to be very plastic throughout it's geographic range. In some streams, thalli are observed yearround (Newfoundland, Ohio); in other streams the thalli are seasonal (Rhode Island October-June, Ohio April-August, Sweden April-October) (KYLIN 1912; Burkholder \& SHeAth 1985, this study). It might not be surprising that an alga would show seasonal differences among these varied geographic locations that are in both boreal and deciduous forest. However, this study is the first to show that the seasonality is variable between two sites in close proximity and the same climatic zone. Therefore, it would appear that locale-scale stream characteristics such as water depth and canopy cover play an important role in gametophyte production as well as potentially large- scale geographic variables.

ACKNOWLEDGEMENTS

We would like to thank Jason Bonham, Wayne Chiasson, Emily Hollingsworth, and Alex Vandenbroek for their assistance in field sampling. We would also like to thank Trey Scott for his help with imaging and analysis of canopy cover.

\section{REFERENCES}

Burkholder, J.M. \& Sheath, R.G. (1985): Characteristics of softwater streams in Rhode Island. I. A comparative analysis of physical and chemical variables. Hydrobiologia 128: 97-108.

Carmona, J.; Bojorge-García, M.; Beltrán, Y. \& RamírezRodríguez, R. (2009): Phenology of Sirodotia suecica (Batrachospermaceae, Rhodophyta) in a high-altitude stream in central Mexico. - Phycol. Res. 57: 118-126.

Carmona, J.; Perona, E.; SÁnchez-Díaz, E. \& Loza, V. (2011): Morphological and ecological characterization of Batrachospermales (Rhodophyta) in the Jarama Basin, Iberian Pennisula. - Limnetica 30: 117-128.

Entwisle, T.J. \& Kraft, G. (1984): Freshwater red algae of South-eastern Australia. - Aust. J. Marine Freshwater Res. 35: 213-259.

Filkin, N.R. \& Vis, M.L. (2004): Phenology of Paralemanea annulata (Lemaneaceae, Rhodophyta) in an Ohio woodland stream. - Hydrobiologia 518: 159-168.

Hambrook, J.A. \& Sheath, R.G. (1991): Reproductive ecology of the freshwater red alga Batrachospermum boryanum Sirodot in a temperature headwater stream. - Hydrobiologia, 218: 233-246.

House, D.L.; VandenBroek, A.M. \& VIS, M.L. (2010): Intraspecific genetic variation of Batrachospermum gelatinosum (Batrachospermales, Rhodophyta) in eastern North America. - Phycologia 49: 501-507.

Kumano, S. (2002): Freshwater Red Algae of the World. 375 pp., Bristol, UK.

KyLIN, H. (1912): Studien über die schedischen Arten der Gattungen Batrachospermum Roth und Sirodotia nov. gen. - Nova Acta Soc. Sci. Upsaliensis 3: 1-40, ser. 4.

Minckley, W.L. \& Tindall, D.R. (1963): Ecology of Batrachospermum sp. (Rhodophyta) in Doe Run, Meade County, Kentucky. - Bull. Torrey Bot. Club 90: 391-400.

Müller, K.M.; Vis, M.L.; Chitasson, W.B.; Whittick, A. \& SheAth, R.G. (1997): Phenology of a Batrachospermum_population in a boreal pond and its implications for the systematics of section_Turfosa (Batrachospermales, Rhodophyta). - Phycologia 36: $68-75$.

NeCchi, O. JR. \& Branco, C.C. (1999): Phenology of a dioecious population of Batrachospermum delicatulum (Batrachospermales, Rhodophyta) in a stream from southeastern Brazil. - Phycol. Res. 47: 251-256.

RIDER, D.E. \& WAGNER, R.H. (1972): The relationship of light, temperature, and current to the seasonal distribution of Batrachosermum (Rhodophyta). - J. Phycol. 8: 323-331. 
SheAth, R.G. \& Burkholder, J.M. (1985): Characteristics of soft water streams in Rhode Island II. Composition and seasonal dynamics of macroalgal communities. - Hydrobiologia 128: 109-118.

SheAth, R.G. \& HambrooK J.A. (1990): Freshwater ecology. - In: Cole, K. M. \& Sheath, R. G. (eds): Biology of the Red Algae. - pp. 423-453, Cambridge University Press, Cambridge.

Thirb, H.H. \& Benson-Evans, K. (1985): The effect of water temperature, current velocity and suspended solids on the distribution, growth and seasonality of Lemanea fluviatilis (C. Ag.), Rhodophyta, in the River Usk and other South Wales rivers. - Hydrobiologia 127: 63-78.
VIS, M.L. \& ENTwISLE, T.J. (2000): Insights into the phylogeny of the Batrachospermales (Rhodophyta) from $r b c \mathrm{~L}$ sequence data of Australian taxa. - J. Phycol. 36: $1175-1182$.

Vis, M.L.; Carlson, T.A. \& Sheath, R.G. (1991): The phenology of Lemanea_fucina (Rhodophyta) in a Rhode Island River, USA. - Hydrobiologia_222: $141-46$.

VIS, M.L.; Sheath, R.G. \& Cole, K.M. (1996): Distribution and systematics of Batrachospermum (Batrachospermales, Rhodophyta) in North America. 8a. Section Batrachospermum: Batrachospermum gelatinosum. - Eur. J. Phycol. 31: 31-40.

(C) Czech Phycological Society (2014)

Received February 4, 2014

Accepted April 7, 2014 